in conversation 


\section{sacred waste}

irene stengs

In "Tourists of History" (2007) Marita Sturken describes how a part of the rubble of Ground Zero-which also contained the remnants of the bodies of those who died in the tragedy-was set apart, to be ceremonially transferred into urns to be distributed among the bereaved families. In her interpretation, Sturken speaks of "[t]he attempt to make the dust sacred, to turn it into a relic" (2007: 165). Yet, my argument is that the dust of Ground Zero was already charged with a sacrosanct value, and that this value enabled the substance to enforce its ceremonial treatment.

The dust of Ground Zero is just one example of a broad category of ambiguous substances and objects that I have come to denote as "sacred waste": material residues and surpluses that cannot be disposed of as just garbage (or rubble), but neither can be kept or left alone. ${ }^{1}$ Its ambiguous nature, charged with a religious, moral, or emotional value on the one hand, but at the same time a kind of leftover for which no proper destination exists, makes sacred waste precarious matter, and hence often a ground for conflict and contestation. Introducing this general notion of sacred waste may help to further foreground the significance of materiality in the production and preservation of meaning. In studies on ritual, religion, and

Irene Stengs is a senior researcher of the Meertens Instituut in Amsterdam and teaches at the Cultural Anthropology Department of the University of Amsterdam. New public rituals, commemorative culture, and heritage formation form her principal interests. Earlier, she conducted research on modern cults, material culture, and social imaginary in urban the Great Modernizer: King Chulalongkorn, Patron Saint of the Thai Middle Class (Singapore University Press, 2009). Recently, she edited a book on the Dutchness of multicultural rituals in the Netherlands (Nieuw in Nederland. Feesten en rituelen in verandering, Amsterdam University Press, 2012). Presently, she has a fellowship at the Netherlands Institute for Advanced Studies.

the sacred, the production of waste has not received much attention yet, probably because of the contradictory connotations and the supposed lack of value or meaning of waste. However, the insight that material produced in the sacralizing process may simultaneously be waste and sacred makes our understanding of the sacred more complex, and exactly therefore contributes to the study of the field of material religion. A focus on the production of waste in the study of ritual and religion as well as a focus on the ritual dimensions of dealing with waste may enrich the understanding of both.

Other examples of sacred waste are the piles of flowers and attributes placed at royal sites in tribute to Princess Diana, the few drops of Christ's transubstantiated blood that remain in the priest's chalice after the Eucharist, worn Qur'ans, mundane objects that were drawn into the ocean by the Japanese Tsunami to be eventually washed ashore in Alaska and Canada, tattered spirit houses in Thailand, holy statuettes from abandoned churches and monasteries in Belgium, and the remnants of a chestnut tree that stood behind the Secret Annex at the Amsterdam Prinsengracht, described by Anne Frank in her diary. As shown by these examples, sacred waste may arise from (religious) ritual, through events of exceptional scale or impact, or consist of damaged sacra. Irrespective of the differences in terms of materials and origin, sacred waste always demands a special treatment: it must be set apart, for instance by being preserved as a relic or as cultural heritage, or requires to be ritually neutralized.

Where sacred waste is regularly produced in established ritual performances, as for instance during the Eucharist, a set ritual protocol serves to neutralize the remaining "waste." Spiritually charged leftovers such as Thai spirit houses or Ndyuka sacrifices ${ }^{2}$ are left to decay at dumping sites demarcated for the purpose (Figure 1). In Cuba, ritual experts of popular religions follow specific procedures to dispose of the hazardous waste produced in the ritual (Wirtz 2009).

Severe consequences may result from treating sacred waste inappropriately. The unfortunate who coincidentally touches 


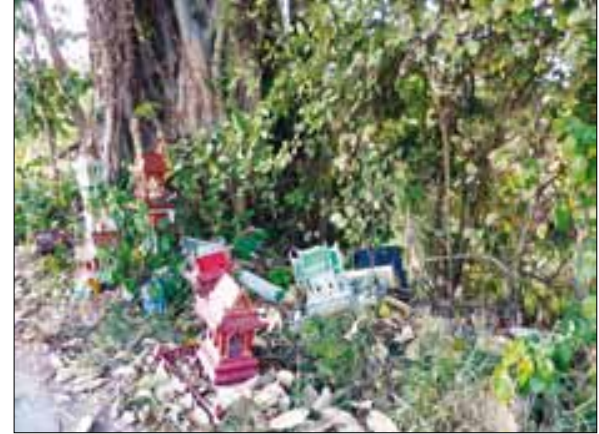

FIG 1

Dumping site for tattered Thai spirit houses (Chiang Mai, January 2010).

the Cuban ritual waste will be afflicted by its negative spiritual energy. In February 2012, the apparently unintentional burning of Qur'ans taken from Taliban prisoners with other waste by the US armed forces in Afghanistan evoked a sequence of violent protest, leaving over 40 people dead and 270 people wounded. At same time, it sparked a debate among Muslim scholars on how old Qur'ans and other religious texts actually should be treated; as it seems, there is not always a protocol guiding our dealings with sacred waste. ${ }^{3}$

My awareness of the existence of something like sacred waste was evoked during my research project on present-day commemorative ritual in the Netherlands (Stengs 2011). Also here, victims of a violent death (killings, traffic deaths, work-related accidents, disaster) as well as deaths of public figures (celebrities, royalty, politicians) are commemorated in the public domain more and more often. For many, such a death is reason to bring objects (cuddle toys, candles, flowers, letters, photographs) to the site where the victims died or to another place associated with the deceased: the material dimension is a central feature of this culture of "new public mourning" (cf. Walter 2008). Material objects are expressions of grief, anger, and empathy; yet, once part of the commemorative space, the objects exert a power of their own.

At many memorial sites - whether modest and ephemeral, or established and permanent-new attributes may be added regularly. After a brief period, most of these attributes begin to disintegrate or decay and assume a gestalt that otherwise implies removal as waste (Figure 2). But in this case, the items usually remain for longer or shorter periods. At the memorial in commemoration of Dutch movie director and social critic Theo van Gogh (assassinated in 2004) attributes usually stay for months until they have nearly decayed. All items left at the Vietnam Veterans' Memorial, on the other hand, are preserved, flowers excepted. Since the National Park Service decided to do so in the early 1980s, over 50.000 items have been collected (Gardner 2011: 287). These examples show that, like in any ritual practice, a process of singularization and sacralization takes place: placed at a memorial site an object becomes incorporated in the memorial and shares in its set-apart, "sacred" status.

In commemorative culture, a precise protocol for dealing with the materials is generally absent. Consequently, the related field of ritual and ceremonial practices is often characterized by uncertainty and ambiguity, particularly when the quantity of the material involved is substantial. This ambiguity stretches also to the material itself. It demands its removal and at the same time forbids a treatment as ordinary waste: it is sacred waste. The eventual dealings with the flowers left after the death of Princess Diana are illustrative: the fresh flowers were selected to be sent to homes for the elderly,

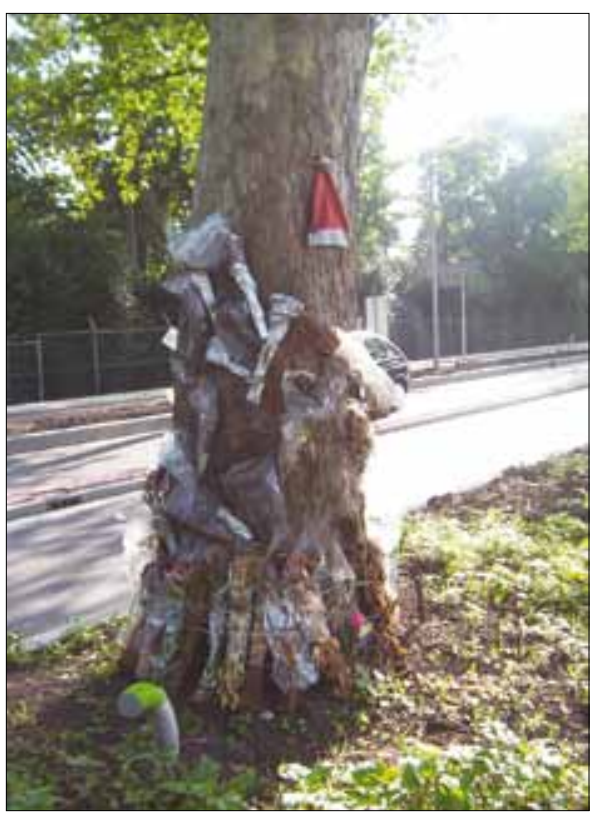

FIG 2

Disintegrated attributes of a roadside memorial-cum-tree in the city of Rotterdam (Netherlands, July 2004). 
while the remaining 10,000 to 15,000 tons of material was composted for use in royal parks. The more durable attributes went to the Spencer family (Greenhalgh 1999: 42, 48). The quantities of memorial material that "inundated" the streets of New York, the Pentagon, and the Flight 93 crash site in Pennsylvania made collectors of these "ephemera of loss," in this case the Smithsonian's National Museum of American History in particular, pose the question "how much of that material could we realistically collect?" (Gardner 2011: 289; italics added) But that these materials had to be preserved was not questioned (although some objected to museums claiming ownership of "personal expressions of grief and loss"): "walking away and allowing the shrines to disintegrate was not responsible, for it would mean the loss of materials that are in the public interest to preserve" (Gardner 2011: 289).

Indeed, there is a growing involvement of museums and academic institutions all over the world in collecting and preserving commemorative material. The fact that it is usually possible to preserve only a selection highlights both the trash and the sacral dimensions of such material. Part of it cannot but be disposed of: it is waste. Part of it must be preserved: it is material with an added distinct, unique value. But which part to preserve and which part to desacralize (see, for example, Figure 3)? By bringing in religious or scientific criteria, the selectors and eventual disposers may be exculpated. Once included in an institutional collection, whether that is labeled as a memento or as cultural heritage, the preserved part becomes a synecdoche for the whole, and may therefore be regarded as a relic.

Historical arguments for preserving reflect the prevalent moral framework. Destroying the material would be an act against ourselves, an act that would deny what we are standing for (or against), or would deny the sacrifices made by those who died. This, again, spotlights the danger for those in charge of the preservation of sacred waste: a social danger, this time. Unjust use or inappropriate treatment may damage the moral reputation of persons and institutions, involving public indignation and the ensuing consequences. The remnants of the so-called "Anne Frank Tree" offer a telling example of the moral load that may burden those in charge of sacred waste (Stengs 2013). Since it fell down in 2010, the remaining 25 tons of wood have been kept in three containers. Disputes about ownership led to a deadlock and hamper finding a destination. Yet, one way out is beyond discussion: disposal. On the contrary, even during storage, the remnants need to be taken care of very well. Disintegration, disposal, or destruction would be tantamount to playing down the importance of "Jewish cultural heritage" or even the memory of the persecution of the Jews under German occupation. Clearly, such highly charged matter is able to rule over those involved in its preservation.

\section{notes and references}

${ }^{1}$ In the literature, I came across a notion of "sacred waste" only once: in an article by Phyllis Passariello (1994) on the ritual (re)use of the human body and its parts, remains and excrements, the placenta in particular. Hence, Passariello basically deals with the sacrality and the sacralization of human waste departing from the question "is anything that once was part of a human ever considered pure waste by humans" (1994: 110, italics in original). In my view, however, sacred waste is a much broader and more encompassing concept.

2 See Thoden van Velzen and Van Wetering on the "sacred dump" of the Surinamese Maroon Gaan Tata cult (2004: 134-6).

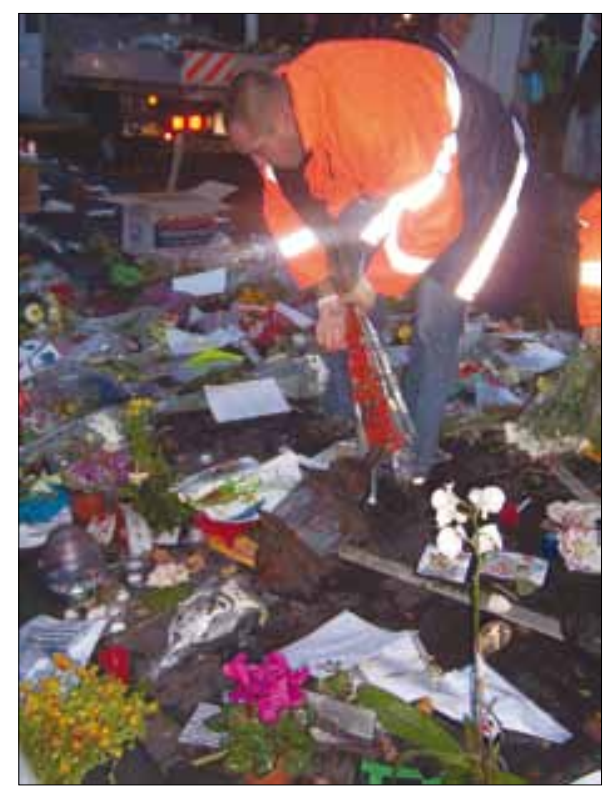

FIG 3

A worker of the sanitation department of Amsterdam selecting items to be preserved as part of the clearing of the Theo van Gogh memorial site, one week after the murder. Most of these items are kept at the Amsterdam City Archives (November 10, 2004). 
${ }^{3}$ The recent suggestion of the Dutch Bible Association (NBG) to recycle old Bibles into paper for printing new Bibles both illustrates the difficulty of discarding sacred material and the absence of protocol (Reformatorisch Dagblad, January 12, 2013).

Gardner, James B. 2011. September 11: Museums, Spontaneous Memorials and History. In Grassroots Memorials: The Politics of Memorializing Traumatic Death, ed. Peter Jan Margry and Cristina SánchezCarretero. New York and Oxford: Berghahn Books, 285-303.

Greenhalgh, Susanne. 1999. Our Lady of Flowers: The Ambiguous Politics of Diana's Floral Revolution. In Mourning Diana: Nation, Culture and the Performance of Grief, ed. Adrian Kear and Deborah L. Steinberg. London and New York: Routledge, 40-59.

Passariello, Phyllis. 1994. Sacred Waste: Human Body Parts as Universal Sacraments. The American Journal of Semiotics 11(1-2): 109-27.

Stengs, Irene. 2011. Sacred Waste: Matter and Meaning in Mourning. Paper presented at the Death,
Dying and Disposal Conference 10, September 9-12, Radboud Universiteit, Nijmegen.

Stengs, Irene. 2013. Branching into Heritage: A Genesis of the Anne Frank Tree and its Multiplications. Paper presented at the Heritage, Performance and the Everyday Conference, January 23-25, Cape Town UWC/UCT.

Sturken, Marita. 2007. Tourists of History: Memory, Kitsch, Consumerism from Oklahoma City to Ground Zero. Durham, NC and London: Duke University Press.

Thoden van Velzen, H. U. E and van Wetering, W. 2004. In the Shadow of the Oracle: Religion as Politics in a Suriname Maroon Society. Long Grove, IL: Waveland Press.

Walter, Tony. 2008. The New Public Mourning. In Handbook of Bereavement Research and Practice: Advances in Theory and Intervention, ed. Margareth S. Stroebe, Robert O. Hansson, Henk Schut, and Wolfgang Stroebe. Washington, DC: American Psychological Association, 241-62.

Wirtz, Kristina. 2009. Hazardous Waste: The Semiotics of Ritual Hygiene in Cuban Popular Religion. Journal of the Royal Anthropological Institute (N.S.) 15: 476-501. 


\section{the accidental, ambivalent, and useless sacred}

\section{david chidester}

Since we are in conversation, I take the liberty of recalling a conversation from January 2013 in Cape Town. At a festive gathering of collaborators on the project, Heritage Dynamics (2011), Irene Stengs inspired us to incorporate Cultural Waste Management, a company staffed by over-qualified heritage consultants, operating under the slogan, "Don't Waste the Future, Clean Up Your Past!" Cultural Waste Management offers the following services: Memory Cleansing, Identity Recycling, Afterlife Management, and Sacred Waste Disposal. By continuing that conversation, Irene Stengs has given us here a compelling profile of sacred waste.

As the old saying goes, "Waste not, want not." What? What could that folk wisdom possibly mean? My doctoral supervisor, the late and great W. Richard Comstock, was fond of observing the ways in which folk wisdom contains aphorisms that cancel each other out, because it urges us to be early birds catching worms, while also admonishing that all work and no play makes us dull. We cannot possibly understand waste and want, the magnitude of leftovers and uses, surpluses and desires, without engaging what Irene Stengs identifies as sacred waste.

David Chidester is Professor of Religious Studies and Director of the Institute for Comparative Religion in Southern Africa (ICRSA) at the University of Cape Town in South Africa. His publications include Savage Systems: Colonialism and Comparative Religion in Southern Africa (University of Virginia Press, 1996), Christianity: A Global History (Penguin, 2000), Salvation
and Suicide: Jim Jones, the Peoples Temple, and Jonestown (Indiana University Press, revised edition 2003), Authentic Fakes: Religion and American Popular Culture (University of California Press, 2005), Wild Religion: Tracking the Sacred in South Africa (University of California Press, 2012), and Empire of Religion: Imperialism and Comparative Religion (Chicago: University of Chicago Press, 2014).
The sacred, that which is set apart, but set apart at the center of social relations, can be regarded as framing what people, adhering to the sacred, hold onto in negotiating their relationships with the sacred. The rest they can throw away. But what if there is no away? If there is no place that is away, how could anyone ever throw anything away, let alone deal with the dilemmas of sacred waste that can be neither kept nor discarded? These are profound questions.

Here I can only highlight what I regard as three important features of sacred waste: its accidental production, its ambivalent valence, and its uselessness in any political economy of the sacred.

Sacred waste is produced by accident. This accidental mode of producing the sacred is a contradiction of terms, an impossibility if we follow the account of the ritual production of the sacred pioneered by Jonathan Z. Smith, because the sacred is produced by factoring out all accidents, creating a perfect pattern of action in which all variables, contingencies, and accidents are controlled (Smith 1982: 63). Sacred waste, however, is produced out of such accidents as a tree falling down, a book growing old, a bunch of flowers fading, or ceremonial gifts being abandoned. Full of sacred aura, these accidental bearers of the sacred are out of control. In some cases, ritual protocols might be developed to contain these accidents, putting them in their place, disposing of them in some prescribed manner, but the accidental production of sacred waste remains a problem for any system of ritual order.

As precarious matter, sacred waste carries an ambivalent electricity-highly charged, negatively charged-recalling the account of the sacred provided by the unconventional Durkheimian Roger Caillois, who argued that the sacred was not merely the opposite of the profane but an efficacious force that is "contagious, fleeting, ambiguous, and virulent" (2001 [1939]: 139). As Stengs observes, ritual procedures might be developed to neutralize the hazardous energy of sacred waste, but Caillois saw such rituals operating not at the margins but at the center of religious practice, 
identifying ritual as an effort to harness the dangerous potency of the sacred, attempting to "capture, domesticate, and engage it in beneficial ways, and if need be, to neutralize its excessive acidity" (2001 [1939]: 151). All of these features of the sacred are evident in sacred waste, so what makes its ambivalent valence distinctive? If it cannot be kept or thrown away, perhaps the distinctive feature of sacred waste is that its excess of acidity can never be captured, domesticated, or neutralized.

Sacred waste might also be distinguished by its uselessness in any political economy of the sacred. As I have argued, the sacred is produced through intensive interpretation and regular ritualization, which generate a surplus of signification and a surplus of power that can be claimed but also contested in struggles over the ownership of the sacred (Chidester 2005, 2012). Not only meaningful but also powerful, the sacred is always owned and operated. In the case of sacred waste, however, the surpluses are leftovers that no one can own. As Stengs observes, this dilemma is evident in tensions between mourners who object to museums "claiming ownership" of memorial objects and the demands of the "new public mourning" that public institutions must own the responsibility of preservation. In this contest over the ownership of the sacred, no one can win. Sacred waste, therefore, is useless in certifying any compelling claim on the ownership of the sacred.

All of this attention to sacred waste, I realize, is exploratory, testing the potential of a new category for analyzing aspects of material religion that are accidental, ambivalent, and useless. If our new company, Cultural Waste Management, takes off, becoming bigger than Apple or Microsoft, I will have to revise my remarks about the uselessness of sacred waste. In the meantime, I thank Irene Stengs for initiating this conversation about sacred garbage, rubble, rubbish, debris, ephemera, leftovers, remnants, and remains.

\section{references}

Caillois, Roger. 2001 [1939]. Man and the Sacred, trans. Meyer Barash. Urbana, IL: University of Illinois Press.

Chidester, David. 2005. Authentic Fakes: Religion and American Popular Culture. Berkeley, CA: University of California Press.

Chidester, David. 2012. Wild Religion: Tracking the Sacred in South Africa. Berkeley, CA: University of California Press.

Heritage Dynamics. 2011. Heritage Dynamics: Politics of Authentication and Aesthetics of Persuasion in Brazil, Ghana, South Africa and the Netherlands. http:// heritage-dynamics.com/ (accessed July 11, 2013).

Smith, Jonathan Z. 1982. Imagining Religion: From Babylon to Jonestown. Chicago: University of Chicago Press. 


\section{sacred waste}

crispin paine

Consumer capitalism, which has served us in the northern hemisphere so well for the past century or so (and many people in the southern hemisphere-so far at least-so badly) is experiencing a distinct wobble. It is not surprising then that there has been increasing attention paid to rubbish. Concern with rubbish links at one end with a theoretical critique of consumer capitalism, at the other with a practical need for free food, which prompts skipping (or "dumpster diving")-and which is also itself a practical critique of consumer capitalism.

Theoreticians have for centuries discussed the nature of the object, but the "material turn" of the past generation has put particular emphasis on the mobility of objects, their constant movement between different understandings and different social contexts. Michael Thompson's Rubbish Theory (1979) showed how things can be either "transient" - things that decrease in value over time and have finite life-spans, like a used car-or "durable" - things that increase in value over time and have (ideally) infinite life-spans, like a Queen Anne tallboy. Objects can, though, move from "transient" to "durable" according to how we understand them, the meaning we ascribe to them, and the way we treat them. But there is also a third category into and out of which objects can move, and that is rubbish.

It is admirable that Irene Stengs has challenged us to consider sacred rubbish and how that differs from any other rubbish. Clearly it does, for it is attributed with different and more powerful meaning. But by including such things as Diana's flowers or the Anne Frank tree Stengs is using "sacred" in a very broad sense. Someone who left a bunch

Crispin Paine is a UK-based museum curator and international heritage consultant, with a special interest in the role of religion in museums. His Religious Objects in Museums: Their Private Lives and Public Roles (Berg, 2012) looks particularly at the curator-object-visitor relationship. of flowers outside Kensington Palace in December 2008 would probably agree that it was significant - to them and to others - but would probably not use the word "sacred." In this area to define "sacred" to include everything set apart is perhaps limiting.

But there is indeed a big overlap between unwanted old things (redundant, wornout, leftovers, remains, or just things out of fashion) that are "sacred" in the everyday, dictionary, sense of made holy by religious association, and similar things that are significant in a non-religious but equally powerful way-like Diana's flowers or the Anne Frank tree.

An Orthodox antimension (altar cloth), when worn out or dirty, shouldat least according to one authoritative commentator - be sent to the bishop's chancery, "where it may be kept in the bishop's chapel, usually under an altar" (Izzo 1975). But this injunction has been far from universally followed: the National Museum in Lviv, Ukraine, has 500 of them.

This is a splendid example of how in the last couple of centuries the museum has been adopted as a proper place to deposit sacred rubbish. Some museums have been set up precisely to fulfill this role: the surge of new diocesan museums and cathedral treasuries of the 1960s and 1970s were a response to the new liturgical practices making sacred objects redundant in many Christian churches, and the decline in religious practice in secular Europe. Back in 2007 Material Religion published JeanFrançois Royal's account of the Museum of Religions at Nicolet, Quebec, which has precisely this role (Royal 2007).

The museum is the modern Geniza for all sorts of significant objects. The deal is that the faithful, in exchange for the free in perpetuum preservation of their sacred rubbish, accept that the museum will transform it from sacred rubbish to work of art or ethnographic specimen. Indeed, this happens with all sorts of things that people care about -things invested with significance-not just those that may be called "sacred" or "religious." Every curator is familiar with the grieving widow who wants the museum to accept something that was 
important to her late partner but for which she can't find a place in her new life. But the museum doesn't care about her or him -it is interested only in whether the object is beautiful, or illustrates a historical period, or is an example of a school of art, or helps in some other way to tell one of its stories (and museums are deplorably bad at recording a donation's significance to its donor, which is always a hugely important part of its story).

Every museum object has been on a journey, and for some the start of that journey was as a sacred object; for many it was as a significant object. A Bitégué figure from the Republic of the Congo was rescued from a missionary's bonfire, entered a private collection, then an exclusive Paris "tribal art" gallery, and ultimately came to the Louvre. It has run the gamut of meaning: religious object, rubbish, curio, commodity, art object, ethnographic specimen (Paine 2013: Fig. 16).

Occasionally museums insist on a donation being clearly redundant before they will accept it. This is true, for instance, of museums of buildings. They don't want to let developers off the hook by clearing their development sites of unprofitable old buildings, but they do want to preserve those buildings if the alternative is their destruction. In this sense museums are indeed the equivalent for objects of mausoleums - a comparison that usually annoys curators intensely.

But these examples are nothing compared with the one big example of significant-or sacred-rubbish: the dead human body. A dead body moves from a "transient" stage (in Thompson's terminology) to a "durable" stage. But in many societies, after a certain amount of time, it may move again - to rubbish. By chance I recently visited the graves of my father, my greatgrandfather, and my great-great-grandfather. The first experience was emotional, the latter two merely curious; the first grave was the bearer of memories, the others weren't. Further back than that, and few people in our society mind if the graveyard is bulldozedour ancestors, because they can't be identified let alone remembered, have become rubbish. "The boundary between rubbish and non-rubbish moves in response to social pressures" (Thompson 1979: 11), and here perhaps is one way that happens.

\section{references}

Izzo, Januarius M. 1975. The Antimension in the Liturgical and Canonical Tradition of the Byzantine and Latin Churches: An Inter-Ritual Inter-Confessional Study. Rome: Pontificium Athenaeum Antonianum.

Paine, Crispin. 2013. Religious Objects: Private Lives and Public Duties. London: Bloomsbury.

Royal, Jean-François. 2007. Protecting and Interpreting Quebec's Religious Heritage: The Museum of Religions at Nicolet. Material Religion 3(1): 153-4.

Thompson, Michael. 1979. Rubbish Theory: The Creation and Destruction of Value. Oxford: Oxford University Press. 
